\title{
ECB: Quo Vadis?
}

\author{
The European Central Bank has implemented a very ambitious monetary policy since the \\ financial crisis of 2008, intervening heavily in the eurozone economies. This policy has \\ generated substantial risks to both the ECB's primary task and its independence. It is \\ therefore time for a fundamental evaluation of the ECB's monetary policy strategy.
}

During and since the financial crisis of 2008, the European Central Bank (ECB) has taken a different policy direction than it had prior to the crisis. This concerns not only the use of so-called unconventional monetary policy instruments, but also the modification of its strategy and the drifting away from a number of core principles of the Treaty on European Union, including the Statute of the European System of Central Banks (ESCB). This article discusses and assesses these changes from the perspective that the financial system and the economy in which the ECB operates are complex adaptive systems. This sets certain requirements for what monetary policy should look like. This article begins with an overview of the changes in the ECB strategy. This is followed by a discussion of what complex adaptive systems are and what requirements for monetary policy follow therefrom. Next, it is argued that since the crisis, ECB policy violates two principles for policy in a complex adaptive system. Certainly in the past four years, the ECB has not been successful in achieving the goals it has set for itself. The ECB's original strategy was more in line with these principles.

\section{ECB strategy and treaty}

The ECB moved away from the principles set out in the Treaty on European Union and the Statute of the ESCB in two essential respects. It has also abandoned its original strategy at two key points. Both cases will now be dealt with in succession.

\section{Drifting away from the Treaty on European Union}

Over the past few years, the ECB has bought massive amounts of debt securities from governments in

Sylvester Eijffinger, Tilburg University, The Netherlands.

Lex Hoogduin, University of Groningen, The Netherlands; and LCH Group, Amsterdam, The Netherlands. the secondary market via its quantitative easing (QE) programme. However this may be judged from a legal standpoint, in economic terms this is clearly monetary financing of government deficits and debts. A basic assumption underlying the EU Treaty and the Statute of the ESCB is that this is not allowed, because a government that can call on the central bank for financing will sooner or later derail and dominate monetary policymaking. The ECB has thereby undermined its independence, as set out in the ESCB statutes. ${ }^{1}$ The basis for ECB independence is the longer-term neutrality of monetary policy. The ECB's current monetary policy is not neutral over the business cycle and has led to large redistribution effects between deficit and surplus countries and between eurozone savers and debtors. In doing so, the ECB has de facto overstepped its mandate. The EU treaty contains the so-called no-bailout clause, which is meant to ensure that countries must keep their own houses in order and will not be bailed out by other countries. The ECB policy has contributed to the undermining of this clause. QE suppresses the interest expenses on government debt. This can easily make countries more careless about taking on more debt, resulting in overly large deficits. ECB President Mario Draghi's famous 2012 declaration that the ECB was ready to do whatever it takes within its mandate to save the euro, including buying an unlimited volume of government bonds from countries in trouble (i.e. outright monetary transactions, or OMTs) if necessary, has the same effect. The difference is that an OMT programme is conditional and was never implemented, while

(C) The Author(s) 2018. Open Access: This article is distributed under the terms of the Creative Commons Attribution 4.0 International License (https://creativecommons.org/licenses/by/4.0/), which permits unrestricted use, distribution, and reproduction in any medium, provided you give appropriate credit to the original author(s) and the source, provide a link to the Creative Commons license, and indicate if changes were made.

1 S.C.W. Eijffinger, J. De Haan: The Political Economy or Central Bank Independence, Princeton Special Papers in International Economics No. 19, 1996; J. De Haan, S.C.W. Eijffinger, S. Waller: The European Central Bank: Credibility, Transparency and Centralization, CESifo Book Series, Cambridge MA 2005, The MIT Press; and J. De Haan, S.C.W. Eijffinger: Central bank independence under threat?, CEPR Policy Insight No. 87, 2017. 
QE has been applied unconditionally and to such a large extent that in the spring of 2018 there were no government bonds available for purchase. ${ }^{2}$

\section{Change of ECB strategy}

The Maastricht Treaty states that the primary objective of the ECB is to maintain price stability. It does not indicate how price stability is defined nor how the ECB should pursue it. The ECB has determined this in its monetary policy strategy, which has been evaluated and clarified after more than four years. ${ }^{3}$

This is important for understanding developments since the financial crisis. The ECB was not meant to be a socalled inflation targeter. In other words, while its primary objective was to ensure price stability, it did not have a defined quantitative target for price stability. Now, however, the ECB does have a definition of price stability: a development of the harmonised index of consumer prices (HICP) for the euro area as a whole of below, but close to, two per cent on an annual basis. This definition of price stability was defined by the ECB prior to the crisis and has not been seriously evaluated by the ECB since then.

The ECB follows a so-called two-pillar strategy. The monetary pillar examines monetary and financial variables to identify signals which may indicate risks to price stability over the medium term. In this context, a guideline for the growth of the money supply in a broad sense (M3) is also formulated. ${ }^{4}$ The second pillar contains an analysis of all developments in the real economy in the medium term with respect to the risks to price stability. This includes the analysis of price indicators other than the HICP.

In addition to the HICP and core inflation, the ECB should also look at the prices of financial assets, such as equities and government bonds, because of possible wealth effects on the prices of goods and services over time. Based on an assessment of both pillars on the risks to price stability over the medium term, the ECB Governing Council applies its primary instrument, the refinancing rate for banks.

Since 2007, the monetary pillar has become less important and has faded into the background. At that time, the ECB stopped publishing a guideline for the growth of M3. Until then, the guideline had always been growth of $4.5 \%$,

2 European Central Bank: Economic Bulletin, No. 2, 22 March 2018.

3 European Central Bank: A Stability Oriented Monetary Policy for the ESCB, 1998; European Central Bank: The ECB's Monetary Policy Strategy, 2003.

4 Ibid. but this was often exceeded. On the eve of the crisis in 2007 , the growth of M3 was $12 \% .^{5}$

Under Draghi, the ECB has, without explanation and substantiation, become an inflation targeter. And a very precise one. Inflation should be $1.8 \%$ or $1.9 \%$ per year if the target is to be achieved. Achieving this level of inflation has been a constant failure of the ECB over the past four years, because structurally lower energy prices have made the achievement of the inflation target impossible. This means that the ECB is currently experiencing the least successful period in its young history, and it is unclear to financial markets which inflation compass the ECB will rely in the medium term - the HICP or an alternative measure.

In its strategy, the ECB also determined that its focus is on actual inflation in the medium term, i.e. on the HICP without correction for fluctuations that disrupt the trend. Such an index is called core inflation or super core inflation. In recent years, the ECB has put core inflation at the heart of its policy.

This focus on core inflation, which is lower than it ought to be, is used by the ECB to justify the large-scale, longterm purchase of government bonds and other debt instruments and for keeping policy rates close to zero - ten years after the start of the financial crisis and at a time when economies in the euro area have already been recovering for a number of years. Actual inflation in the euro area is about half a percentage point lower than the ECB target. But the danger of a deflationary spiral, if it ever existed, has disappeared. The current level of inflation seems to be rather safe, but the same cannot be said of current ECB monetary policy, which can be characterised as "the ends justify the means". However, this is not the type of policy that the Maastricht Treaty instructs the ECB to follow. Indeed, the prohibition on monetary financing is meant to impose restrictions on those means.

\section{Risks of the ECB policy}

The ECB's current unconventional monetary policy carries major risks:

- Moral hazard: Governments might postpone necessary fiscal adjustments or try to avoid them altogether. These adjustments could include measures related to the size of government deficits; actions to make markets work better; and efforts to reorganise the balance sheets of banks, companies, or citizens. An example of the effects of moral hazard is offered by France, where

5 European Central Bank: Monthly Bulletin, January-December 2007. 
despite the current positive economic development and very low interest rates, the budget deficit still exceeds three per cent of GDP. Another example is the fact that ten years after the start of the crisis, there are still nearly $€ 1$ trillion worth of non-performing loans on the balance sheets of banks in the euro area, despite the fact that it was agreed in the framework of the European banking union to clean up bank balance sheets. The very low interest rates make it easy for Italian banks to roll over non-performing loans.

- Speculative bubbles: Prolonged low nominal and real interest rates can create speculative bubbles. In the current situation, there are a multitude of examples: government bonds, corporate bonds, stocks, real estate and even cryptocurrencies. It is clear that the development of prices in these markets has been distorted by the ECB.

- Boom/bust cycles: According to Austrian economic theory, an overly accommodative monetary policy leads to so-called boom/bust cycles. ${ }^{6}$ An interest rate that is too low, i.e. one that does not reflect the equilibrium interest rate but is heavily influenced by the ECB's QE programme, gives an inconsistent signal to consumers and investors, both of whom will expand their spending. This yields strong economic growth (boom), but that growth is not sustainable. It is accompanied by misallocations. More production capacity is built up during the boom than is necessary to deliver intended future consumption. This leads to a recession (bust) and rising unemployment.

- Elimination of market forces and biased measurement of economic quantities: The ECB has become a dominant player in financial markets. This influences the behaviour of other market parties, who are less interested in the creditworthiness of the issuer of debt instruments and more in the modalities of the ECB monetary policy. The ECB thus not only determines the money market interest rates but also those in the capital market, which should not be the central bank's domain. Moreover, the Dutch and German budget surpluses are also partially due to the artificially low interest rates. If the interest rate were two to three percentage points higher, which would not be inconceivable in the current economic climate, then these surpluses would quickly disappear.

6 F.A. Hayek: Prices and Production, 2nd edition, New York 1932, August M. Kelly Publishers; L. Von Mises: The Theory of Money and Credit, New York 1912, Skyhorse Publishing.
- Reducing productivity growth and therefore economic growth: Low-yielding production capacity can be maintained through very low interest rates. However, this slows down innovation and shifts capacity away from more productive activities. In this way, the ECB's monetary policy contributes to a relatively slow and limited recovery after the crisis.

- Inflation: The longer the policy is sustained in an environment of robust growth, the greater the risk of reaching a tipping point when inflation suddenly starts to accelerate. We do not know where that tipping point is.

- Loss of credibility: The ECB will no longer be afforded the same level of confidence as it continues to undershoot its inflation goal of close to but below two per cent.

- Loss of support for the independence of the ECB: As it exerts a more permanent influence on matters (e.g. pensions) that extend far beyond its primary goal of maintaining price stability, other actors are more likely to question the ECB's independence. The longer-term neutrality of money is a condition for central bank independence, and thus monetary policy must avoid (large) redistributive effects between and within the eurozone economies over the various business cycles.

\section{Policy in a complex adaptive economy}

The economy is a complex adaptive system (CAS), ${ }^{7}$ which can be defined as a large set of heterogeneous economic agents who interact with each other and who also respond and adapt to their environment. A CAS is therefore dynamic and permanently evolving.

The actual development of an economy depends on knowledge, information, preferences and expectations about the future. These data can never be obtained centrally, as they are too scattered among billions of individuals. ${ }^{8}$ Moreover, much of the knowledge and information used by individuals - particularly with regard to preferences and expectations - are not recorded or cannot be

7 See W.B. Arthur: Complexity and the Economy, Oxford 2015, Oxford University Press; C. Colander, R. Kupers: Complexity and the Art of Public Policy. Solving Society's Problems from the Bottom Up, Princeton 2014, Princeton University Press; C. Diks: Complexity and Economics, Oration, University of Amsterdam, 2012; F.A. Hayek: The Theory of Complex Phenomena, in: F.A. Hayek: Studies in Philosophy, Politics and Economics, London 1967, Routledge \& Kegan Paul, pp. 22-42; L. Hoogduin: Dealing with Complexity and Uncertainty, Inaugural Address, University of Groningen, 2014; M. Mitchell: Complexity: A Guided Tour, New York 2009, Oxford University Press.

8 F.A. Hayek: Economics and Knowledge, in: Economica, Vol. 4, No. 13, 1937, pp. 33-54; F.A. Hayek: The Use of Knowledge in Society, in: American Economic Review, Vol. 35, No. 4, 1945, pp. 518-530. 
recorded. As a result, economic development is highly unpredictable, and unintended consequences from interventions in the economy are always possible. There is Knightian uncertainty, in which the future is unknown and unpredictable due to geopolitical and other risks. ${ }^{9}$ Economic and hence monetary policy that takes into account the fact that the economy is a CAS is based, among other things, on two principles. ${ }^{10}$ The first is modesty. Policy cannot be used to create the right conditions. It cannot pursue precise outcomes as knowledge is lacking for this. To attempt to do so is hubris and ultimately leads to failure. ${ }^{11}$

The second principle is caution. Policy should not cause damage. This principle is also found in medicine, going back to Hippocrates: "First do no harm". It is in line with the acknowledgement that the policymaker knows very little about the precise development of a CAS, while that system itself has adjustment mechanisms which must be allowed to do their job. According to Hayek, we can at best know which mechanisms work in a CAS. There are no constant quantitative economic laws. ${ }^{12}$ The most important task of an economist is to constantly explain how little we can know about the economy in which we want to continually intervene. As such, policymakers should not implement policies that can potentially do more damage than good. The goal can never justify the means. The cure must not be worse than the disease. Policymakers must also ensure that they do not become a source of disruptions by intervening too strongly and too often. They should strive to be as predictable as possible and conduct policies based on simple rules with as little discretion as possible. This is in line with the discussion on "rules rather than discretion" in monetary policy and Friedman's fixed monetary growth rule. ${ }^{13}$

\section{ECB policy and complexity}

The ECB's current monetary policy violates both of these prudential policy principles in a CAS. It is not modest. The

9 F. Knight: Risk, Uncertainty and Profit, Boston and New York 1921, Mifflin.

10 L. Hoogduin: Complexity, Modesty and Economic Policy, in: OECD: Insights into Complexity and Policy, New Approaches to Economic Challenges, 2016, pp. 11-12; and L. Hoogduin: Complexiteit, onzekerheid en (macro-)economisch beleid, in: Sturen in een verweven dynamiek, Ministry of Economic Affairs of the Netherlands, 2017, pp. 5968.

11 S. Brakman, L.H. Hoogduin, H. Garretsen: Overconfidence in Monetary Policy, in: E. Wester, G.H. Kuper, E. Sterken (eds.): Coordination and Growth: Essays in Honour or Simon K. Kuipers, Dordrecht 2001, Kluwer, pp. 164-178.

12 F.A. Hayek: Economics and..., op. cit.; F.A. Hayek: The Use of... op. cit.; and L. Von Mises: The Ultimate Foundation of Economic Science, Indianapolis 1962, Liberty Fund.

13 See R.J. Barro, D.B. Gordon: Rules, Discretion and Reputation in a Model of Monetary Policy, in: Journal of Monetary Economics, Vol. 12, No. 1, 1983, pp. 101-121; and M. Friedman: A Program for Monetary Stability, New York 1960, Fordham University Press.
ECB has become an inflation targeter with a very precise target for a precisely defined variable (HICP) that is structurally undershooting inflation and thus will undermine the credibility and independence of the ECB over time. Furthermore, the risks inherent in the ECB's current policy are large, while the ailment itself seems relatively minor: inflation that is a little lower than desired, but without much risk of becoming deflation. The irony is that the original two-pillar strategy of the ECB better meets the requirements for policy in a CAS. There was no inflation target, and the monetary pillar was intended to contribute predictably to the creation of conditions for price stability over the medium term. The ECB should consider returning to its original strategy.

\section{Conclusion}

The ECB is not the only central bank with a problematic strategy. In fact, all central banks that are inflation targeters, i.e. pretty much all of them, face this problem. The remarkable thing is that the ECB did not adopt the strategy of inflation targeting until the very moment that problems with the strategy became visible. Furthermore, once it did adopt this flawed strategy, it then also set a very precise target.

What is needed is a fundamental review of the strategy of inflation targeting. The aim of such a review would be to bring back modesty and prudence to the manner in which monetary policy is conducted. This need has only increased because of the existence of Knightian uncertainty, which confronts all central banks. Until recently, important central banks, such as the ECB and the Federal Reserve System, have shown few signs of wanting to conduct such a review of their monetary policy strategies. However, there has been increasing concern among some leading central bankers that the models that are used in the context of inflation targeting no longer work. ${ }^{14}$

While we welcome this policy re-evaluation, we fear that they are looking for the solution in the re-specification of their policy models. They will search for knowledge about the inflation process and the economy, which in principle is not available. The answer cannot come from alternative policy models, but rather from a different strategy. Specifically for the ECB, this means that no policy should be pursued that is at odds with the principle of the prohibition of monetary financing. Finally, the policy should preferably be in line with the no-bailout clause instead of undermining it. QE and OMTs should therefore not be part of the ECB's regular policy instruments.

14 C. Giles: Setting Policy in the Dark, Financial Times, 12 October 2017, p. 7. 